\title{
Build Ecopreneurship College Student Through Design Game As Learning Media of Chemistry On Media Lecture Game of Chemistry
}

\author{
Achmad Lutfi*, Rusly Hidayah, Dian Novita \\ dept.of Chemistry \\ Universitas Negeri Surabaya \\ Surabaya, Indonesia \\ achmadlutfi@unesa.ac.id
}

\begin{abstract}
This research aim for measured success train ecopreneurship college student through design game as a learning medium chemistry on game media course chemistry. On media courses game of chemistry, college student divided in groups given task project for compile plan ICT game as a learning media of chemistry. Plan, the resulting game rated by media experts who master chemistry, aspects rated covering requirements game as a learning medium, level renewal plan game, and accuracy plan take decision. Results assessment to three plan ICT game shows on aspect requirements game as a learning medium have been obtained score $82 \%$ to $93 \%$, level novelty plan game obtained score by $84 \%$ to $86 \%$, and ability plan take decision obtained score $86 \%$ to $97 \%$, results that have been required the prescribed criteria, ie more large $80 \%$. Concluded that with design game as a learning media of chemistry could train ecopreneurship college student on aspect develop ideas and design take decision.
\end{abstract} chemistry

Keywords: ecopreneurship, games, media course

\section{INTRODUCTION}

The role of the lecturer includes planning, teaching and educating, assessing, analyzing and teaching is a complex task. As a lecturer will make envoy lot when learning takes place, too many things to do to get a chance for finish learning. According to the curriculum of chemistry education department FMIPA Universitas Negeri Surabaya stated that learning was not only aimed at making students master the lecture material as much as possible but it was expected that during lectures students were able to develop and actualize ecopreneurship values [1].

Operationally courses in chemistry education study programs should reveal the copreneurship, meaning lectures in chemistry education department of the FMIPA Unesa measured the extent to which ecopreneurship can be achieved according to the indicators that have been formulated. In the lecture on media lecture game of chemistry, students are expected to have the ability to design and make prototypes of the game as learning media manually or using computer ICT. The hope of the lecture above shows that students are required to be able

Courses that can train ecoprenseurship one of them is the chemical game media and based on the description of the problems above, it is necessary to do research on whether by designing games with ICT as a medium of learning to innovate or develop new ideas in designing games as a medium for learning chemistry.

Game is one of the learning media that has advantages, among others, by playing students recognize patterns that exist in certain situations [6]. The game has several advantages, namely: challengin $\mathrm{g}$, fun, and very close to students' lives [2]. Through the game students can demonstrate ability in overcoming problems and mastery of knowledge and skills learned [3]. The game can provide a diverse learning experience and can be used for a variety of classrooms. The game is also an effective way in order to mem $p$ eroleh attention of students to study particular topic or skill [4]. Games can bring competition to students and only want to win so that lacking the role of learning media therefore requires certain requirements that must be met. When developing games using ICT as a medium of learning chemistry must pay attention to aspects as a game, as a learning medium, and the truth of the chemistry material that is taught . Chemistry learning with games that have fulfilled the requirements as learning media can create active students learning [17]

In developing the game as a medium of learning requires ideas or ideas that demand innovation efforts by the developer and it needs to be trained in various lecture activities and one of the other requirements is in the game there are decision-making activities. Because the game is designed as a learning medium, it must meet the requirements of the requirements as a learning medium [5].

Another advantage in games, can challenge and delight students, the game can also provide a diverse learning experience for students. Another advantage of the game as a medium of learning, namely: (a) students actively involved in learning, (b) games in accordance with learning objectives, and (c) games can be used in a variety of classroom setting, ranging from all students in the classroom to individual activities, (d) games can be an effective way to get the attention of the students to learn specific topics or skills [4]. The success rate of the game as a learning medium is the achievement of learning goals. Games can be used as learning media when it meet the criteria as learning media and game criteria.

chemistry, can build ecopreneurship students on aspects of new ideas and designing decisionmaking activities. 


\section{RESEARCH METHODS}

\section{A. Research Design}

The design of this study is in the form of providing project assignments to the research objectives, namely in the form of a computer game plan as a medium for chemistry learning. The task group was given after following the lecture $m$ edia $p$ ermainan $\mathrm{k}$ Imia, $\mathrm{p}$ enyusun an ITC refuge game development plan based on specific criteria. The results of the project assignments are assessed using established guidelines.

\section{B. Research Instruments}

During the study, several instruments were needed to obtain research data, as follows. Game plan assessment sheet, used to measure the level of fulfillment of the criteria for the game as a medium for chemistry learning. Novelty level assessment form a game plan, used to get novelty data on a game plan that developed by student. Appraisal of aspects of decision making, used to measure students' ability to design games so students can practice making decisions.

\section{RESULTS AND DISCUSSION}

Has obtained 3 ICT game plan, that by the name of (1) Carbon Dash Game, (2) Super Chemistry Game, and (3) Wind's Maze Chemistry Game, briefly following the third game.

Carbon Dash, an endless run game in which there are 4 levels, students use the character of $\mathrm{Mr}$. Carbon in the form of a gorilla is black and has 3 lives that will pass through many obstacles to get bananas. After getting 10 bananas, a question will appear that must be answered in order to proceed to the next level. To help students face difficulties answering questions provided appropriate hydrocarbon material.

Super Chemistry (Super Chem), an androidbased game as a tutorial game, this game contains the guidance of learning activities to achieve the learning objectives of the specified electrolyte and non-electrolyte solution materials. In the opening part of the game there are several choices, namely the competencies that are expected to be achieved, the material to be studied, and the play. Permaiman consists of 4 levels at each level beginning with collecting various kinds of solutions according to the specified categories, then the questions are available to be answered and if the wrong answers are prepared the choice to stop or learn the material according to the level but if the correct answer the player can proceed to the next level by collecting several solution as specified. And so on up to level 4 , the game will be finished if the game over or has been able to go through to level 4 .

Wind's Maze Chemistry played i ndivid ual but students can work together if you have trouble answering questions. This game can be played with a mobile or tablet offline. Players are likened to

\section{Analysis of research data}

Data from expert assessment to the game plan as a learning medium comprising chemical aspects (a) game requirements, (b) novelty, and (c) aspects of the train take a decision, carried out by calculating the average of three assessors (scores 1 to 5) in each aspect. The average of each aspect obtained is converted into percentages and the conversion results are interpreted into Table 1 . Assessment is said to have fulfilled if all aspects of the game plan had reached the criteria of meeting $81 \%$ greater $(>$ $80 \%$ ).

TABLE I INTERPRETATION OF ASSESSMENT RESULTS

\begin{tabular}{|c|c|}
\hline Percentage & Criteria \\
\hline $0 \%-20 \%$ & Not very fulfilling \\
\hline $21 \%-40 \%$ & Less fulfill \\
\hline $41 \%-60 \%$ & Enough to meet \\
\hline $61 \%-80 \%$ & Meet \\
\hline $81 \%-100 \%$ & Very fulfilling \\
\hline \multicolumn{2}{|c|}{ Riduwan [19] }
\end{tabular}

students who will complete the mission. The game has 3 levels with the theme of maze, the playing ethics will be provided with books containing learning material in accordance with the learning objectives in the game. Questions or questions will appear if the player has received 3 coins. Players will collect coins and there are stars as lives. If the answer to the question is wrong then the choice is given to start playing again or read the subject matter according to the problem.

The first category assessed on the game plan regarding game requirements includes: aspects of content requirements and aspects of construct requirements: aspects of chemistry, encouraging developing specific skills, suitability with student characteristics, having rules, having guiding elements, competition, requirements, and strategy in playing, having standards of student success, challenging students and engaging students, giving feedback. The second category that was judged by the game's renewal and the third category which was judged by the game plan trained to make decisions. The results of the assessment of 3 game designs by three experts are presented in the following tables.

\section{A. Game requirements as a medium for learning chemistry}

The data above shows the requirements for the contents of the game plan have reached score $89 \%$ to $91.0 \%$, the score has met the criteria and $\mathrm{p}$ no requirement constructs of the game got a score of $82 \%$ to $97 \%$ and the score that it meets the criteria, ie $\mathrm{m}$ inimal $81 \%$. Meeting the requirements of the contents of the game, meaning that the concept of chemical materials in the game already meets the truth of the contents, has been declared true and has 
been in accordance with the expected learning objectives. This is consistent with the opinion of Ismail [7], Barnes, Mosgrove, and Rassouli [8], Fenrich [9] that $\mathrm{s}$ ne games developed must have the truth of the contents and has the appropriate destination. The determination of the learning objectives is the main reference in determining the learning media, this is in accordance with the views of Bates [13], Kusnadi \& Sutjipto [14], Indriana [15]. More detailed goals that can be sorted will make it easier to sort the teaching material that students will learn [16].

The results of the assessment of game requirements for the three game plans are presented in Table 2.

The game plan has fulfilled the construction requirements for computer / ICT game play as a medium for chemistry learning . Meeting the requirements of the construct of the game, meaning the game plan has met characteristics of chemistry, the push to develop specific skills, compliance with the characteristics of students, has a rule, have a guiding element, there is competition, requirements, and strategies in play, with meeting student success, challenges students and involving students, giving feedback.
In terms of construct game's score of $82 \%$, ie at encouraging aspects of developing specific skills and aspects there is no strategy berm a competition in. These results indicate that students still have difficulty designing games on aspects of training specific skills related to chemistry learning and students are still having difficulty designing games that can show competition, there are challenges that need strategies in winning the game.

The highest score of construct requirements of $97 \%$ was obtained in the aspect of challenging students playing, meaning students have been able to design games that challenge students in playing. The aspect of conformity with the characteristics of students and planning feedback in the game scored $93 \%$, this result shows the game plan has paid attention to the characteristics of student learning and this is in line with the opinion of Smaldino et al. [4] , that choosing media must pay attention to the characteristics of student learning styles, that chemistry has certain characteristics. The data provides information that students already have the ability to design games according to the characteristics of students and one of them is challenging students to play.

TABLE II RESULTS OF GAME REQUIREMENTS ASSESSMENT

\begin{tabular}{|c|c|c|c|c|c|}
\hline \multirow[t]{2}{*}{ No. } & \multirow[t]{2}{*}{ Aspects / Indicators } & \multicolumn{3}{|c|}{ Rating result } & \multirow[t]{2}{*}{ Average } \\
\hline & & Plan 1 & Plan 2 & Plan 3 & \\
\hline A & \multicolumn{5}{|l|}{ Content Requirements } \\
\hline 1 & Truth contents & $\begin{array}{c}4.33 \\
(86 \%)\end{array}$ & $\begin{array}{c}4.33 \\
(86 \%)\end{array}$ & $\begin{array}{c}4.66 \\
(93 \%)\end{array}$ & $\begin{array}{c}4.44 \\
(89 \%)\end{array}$ \\
\hline 2 & Have a goal (knowledge structure) & $\begin{array}{l}4.33 \\
(86 \%)\end{array}$ & $\begin{array}{l}5.00 \\
(100 \%)\end{array}$ & $\begin{array}{l}4.33 \\
(86 \%)\end{array}$ & $\begin{array}{c}4.55 \\
(91 \%)\end{array}$ \\
\hline $\mathrm{B}$ & \multicolumn{5}{|l|}{ Construction Requirements } \\
\hline 1 & Characteristics of Chemistry & $\begin{array}{c}4.00 \\
(80 \%)\end{array}$ & $\begin{array}{c}4.66 \\
(93 \%)\end{array}$ & $\begin{array}{c}4.33 \\
(86 \%)\end{array}$ & $\begin{array}{c}4.33 \\
(86 \%)\end{array}$ \\
\hline 2 & Encourage developing special skills & $\begin{array}{c}4.00 \\
(80 \%)\end{array}$ & $\begin{array}{l}4.33 \\
(86)\end{array}$ & $\begin{array}{c}4.00 \\
(80 \%)\end{array}$ & $\begin{array}{c}4.11 \\
(82 \%)\end{array}$ \\
\hline 3 & Conformity with student characteristics & $\begin{array}{c}5.00 \\
(100 \%)\end{array}$ & $\begin{array}{c}4.33 \\
(86 \%) \\
\end{array}$ & $\begin{array}{c}4.66 \\
(93 \%) \\
\end{array}$ & $\begin{array}{c}4.66 \\
(93 \%) \\
\end{array}$ \\
\hline 4 & Have a rules & $\begin{array}{c}4.33 \\
(86 \%)\end{array}$ & $\begin{array}{c}4.66 \\
(93 \%)\end{array}$ & $\begin{array}{c}4.00 \\
(80 \%)\end{array}$ & $\begin{array}{c}4.33 \\
(86 \%)\end{array}$ \\
\hline 5 & Have a guiding element & $\begin{array}{c}4.33 \\
(86 \%)\end{array}$ & $\begin{array}{c}4.33 \\
(86 \%)\end{array}$ & $\begin{array}{c}4.66 \\
(93 \%)\end{array}$ & $\begin{array}{c}4.44 \\
(89 \%)\end{array}$ \\
\hline 6 & There are competition, requirements and strategies in playing & $\begin{array}{c}4,00 \\
(80 \%)\end{array}$ & $\begin{array}{c}4,33 \\
(86 \%)\end{array}$ & $\begin{array}{c}4,00 \\
(80 \%)\end{array}$ & $\begin{array}{c}4,11 \\
(82 \%)\end{array}$ \\
\hline 7 & Have a standard of student success & $\begin{array}{c}4.33 \\
(86 \%)\end{array}$ & $\begin{array}{c}4.33 \\
(86 \%)\end{array}$ & $\begin{array}{c}4.66 \\
(93 \%)\end{array}$ & $\begin{array}{c}4.44 \\
(89 \%)\end{array}$ \\
\hline 8 & Challenging students and involving students & $\begin{array}{r}5.00 \\
(100 \%)\end{array}$ & $\begin{array}{r}4.66 \\
(93 \%)\end{array}$ & $\begin{array}{r}5.00 \\
(100 \%)\end{array}$ & $\begin{array}{c}4.88 \\
(97 \%)\end{array}$ \\
\hline 9 & Provide feedback & $\begin{array}{c}4.66 \\
(93 \%)\end{array}$ & $\begin{array}{c}4.66 \\
(93 \%)\end{array}$ & $\begin{array}{c}4.66 \\
(93 \%)\end{array}$ & $\begin{array}{c}4.66 \\
(93 \%)\end{array}$ \\
\hline
\end{tabular}

The other aspects score between $86 \%$ to 89 $\%$ on aspects of chemistry, training special skills, having rules, elements of encouraging $g$ and giving feedback. This means that students are able to afford mer e ncanakan game these aspects. The aspect of chemistry as a feature in chemistry learning so that the media of chemistry learning must fulfill this aspect, this is in accordance with
Belll's opinion [10], that chemical learning must be characterized by chemistry. Rules are needed in the game because the game will be able to run if there are rules [11] and the element of guiding players is needed in order to achieve goals, guidance will be reduced according to the needs of players [4]. Feedback in the game as a learning medium is needed for success in achieving goals [12]. 
The result of the above discussion shows plan of the game has been designed so that can be useful to educate children, so that it can be stated students have been able to draw up a game plan in accordance with the requirements of content and construct. As a whole, the three game plans have shown that the game's requirements are as a medium for chemistry learning, so that if it is realized, the game is in accordance with the requirements of the learning media. This is in accordance with Norman's opinion [18] the game with ICT has fulfilled as a medium of learning will be able to create an effective learning environment.

\section{B. Game renewal}

The assessment results of novelty in ICT game planning that includes novelty of stories and displays were presented in Table 3 .

Table 3 above shows that the novelty aspect has reached $84.0 \%$ to $86.0 \%$ meets the specified criteria, meaning that the game plan has brought new game stories and game views so that in drafting the game plan can train new ideas that is part of ecopreneurship. The above results reflect the provision of structural task which the form of designing the game can bring new ideas of students and it is becoming chemistry education department curriculum expectations FMIPA Unesa [1].

\section{Planning makes decisions}

The assessment results to make decisions to the game plan by three assessors are presented in Table 4. Planning makes decisions in this study include: the availability of menu the choice at the beginning of the game, the option to continue or stop at each stage / level, the availability of the option to repeat the game or not at the end of the game.

Based on Table 4 shows the score reached $86.0 \%$ to $97.0 \%$, the lowest score on the aspect there was an advanced choice or stopped at each level and the highest in the aspect on the initial menu there was a choice. All aspects have met the specified criteria so that it can be said students in preparing a game plan have been able to make a decision, this is in accordance with the opinion of Smaldino et al. [4] that the game must be able to train students to make decisions and the ability to make decisions is one indicator ecopreneurship at the Department of Chemistry FMIPA Unesa [1].

TABLE III. NOVELTY RESULTS

\begin{tabular}{|c|c|c|c|c|c|}
\hline \multirow[t]{2}{*}{ No. } & \multirow[t]{2}{*}{ Novelty Aspects } & \multicolumn{3}{|c|}{ Rating result } & \multirow[t]{2}{*}{ Average } \\
\hline & & Plan 1 & Plan 2 & Plan 3 & \\
\hline 1 & Story / scrips game & $\begin{array}{c}4.33 \\
(86 \%)\end{array}$ & $\begin{array}{c}4.66 \\
(93 \%)\end{array}$ & $\begin{array}{c}5.00 \\
(100 \%)\end{array}$ & $\begin{array}{c}4.33 \\
(86 \%)\end{array}$ \\
\hline 2 & Display & $\begin{array}{c}4.0 \\
(80 \%)\end{array}$ & $\begin{array}{c}4.33 \\
(86 \%)\end{array}$ & $\begin{array}{c}4.33 \\
(86 \%)\end{array}$ & $\begin{array}{c}4.22 \\
(84 \%)\end{array}$ \\
\hline
\end{tabular}

TABLE IV. RESULTS OF DECISION MAKING

\begin{tabular}{|c|c|c|c|c|c|}
\hline \multirow[t]{2}{*}{ No. } & \multirow[t]{2}{*}{ Decision Making Aspects } & \multicolumn{3}{|c|}{ Rating result } & \multirow[t]{2}{*}{ Average } \\
\hline & & Plan 1 & Plan 2 & Plan 3 & \\
\hline 1 & The initial choice of the game & $\begin{array}{c}4.66 \\
(93 \%)\end{array}$ & $\begin{array}{c}5.00 \\
(100 \%)\end{array}$ & $\begin{array}{r}5.00 \\
(100 \%)\end{array}$ & $\begin{array}{c}4.88 \\
(97 \%)\end{array}$ \\
\hline 2 & Option to continue or stop at each level & $\begin{array}{c}4.00 \\
(80 \%)\end{array}$ & $\begin{array}{c}4.66 \\
93 \%)\end{array}$ & $\begin{array}{c}4.33 \\
(86 \%)\end{array}$ & $\begin{array}{c}4.33 \\
(86 \%)\end{array}$ \\
\hline 3 & Options to repeat playing or stop & $\begin{array}{c}5.00 \\
(100 \%)\end{array}$ & $\begin{array}{c}4.66 \\
(93 \%)\end{array}$ & $\begin{array}{c}4.66 \\
(93 \%)\end{array}$ & $\begin{array}{c}4.77 \\
(95 \%)\end{array}$ \\
\hline
\end{tabular}

\section{CONCLUSIONS AND SUGGESTIONS}

Based on the data obtained and the discussion can be concluded and suggestions as follows.

\section{A. Conclusion}

Planning of ICT game as a learning medium can train ecopreneurship chemistry student which includes developing an idea or ideas and planning decision.

\section{B. Suggestion}

Lectures should be in the chemistry education study program designed to train ecopreneurship so that indicators will be quickly reached that has been formulated.

\section{REFERENCES}

[1] FMIPA Unesa Curriculum Development Team. "Guidance on Implementation of KKNI and SN-DIKTI Curriculum characterized by Ecopreseurship FMIPA Unesa," Surabaya: FMIPA Unesa. 2016.

[2] Prensky, M. "Digital Game-Based Learning," New York, NY: MacGraw Hill. 2001. 
[3] Personal, BA. "ASSURE Model for Designing Successful Learning,” Jakarta: Dian Rakyat. 2011.

[4] Smaldino, S., Lowther, DL, \& Russell, JD. "Intructional Technology \& Media For Learning: Learning and Media Technology for Learning," Ninth edition. Arif Rahman's translation. Jakarta: Kencana. 2012.

[5] Lutfi, A. "Quality Document for Game Development with Computer as a Learning Media for Science," (Dissertation Summary). ISBN: 9786021083826. Surabaya: Postgraduate Unesa . 2017.

[6] Moursund, D. "Introduction to Using Games in Education: A Guide for Teachers and Parents," United States: University of Oregon. 2007.

[7] Ismail, A. "Education Games" Yogyakarta: Pillar of Media. 2006.

[8] Barnes, J., Mosgrove, B., \& Rassouli, J. "An Objective and Task Media Selection Decision Model and Advertising Cost," Journal of Advertising, 11 (4) . 1982.

[9] Fenrich, P. "Pratical Guidelines for Creating Instructional: Multimedia Applications," Fart Worth: The Dryden Press. 1997.

[10] Bell, RL. "Teaching the Nature of Science through Process Skills Activities for Grades 3-8," USA: Pearson Education, Inc. 2008

[11] Darmawan, D. "Educational Innovation Approach to Multimedia Technology and Online Learning Practices," Bandung: PT Remaja Rosdakary. 2012.

[12] Sadiman, A. "Media Education Series Definition, Development and Utilization," Jakarta: PT Raja Grafindo Persada. 2012.

[13] Bates, AW "Technology, Open Learning and Distance Education," Routledge: London. 1995.

[14] Kustandi, C., \& Sutjipto, B. "Manual and Digital Learning Media," Bogor: Ghalia Indonesia. 2011.

[15] Indriana, D. "Variety of Teaching Media Tools Know, Design and Practice it," Jogjakarta: DIVA Press. 2011.

[16] Valeridi, C. "10 Steps to Design a Game for Learning (Online),"

http://chloeatplay.tumblr.com/post/9350161006/10-stepsto-design-a-game-for-learning-including (accessed April 5, 2013). 2011.

[17] Lutfi, A \& Hidayah, R. "Activiting Student to Learn Chemistry using Chemmy Card 6-1 Games as Instructional Medium in IUPAC Nomenclature of Inorganic Compounds," Journal of Physics: Conference Series . Ser. 953012198. 2018

[18] Norman, D. "Things that make us smarte Defending Human attributes in the age of the machine," New York: Addison-Wesley. 2003.

[19] Riduwan. "Research Variables Measurement Scale," Bandung: Alfabeta. 2015. 